\title{
Necrotizing ulcerative stomatitis mimicking erythema multiforme pada pasien dengan HIV seronegatif
}

\author{
Eliza Kristina Munthe ${ }^{1 *}$, Riani Setiadhi ${ }^{2}$
}

\begin{abstract}
1Divisi Penyakit Mulut, Rumah Sakit Umum Daerah Raden Mattaher Jambi, Indonesia ${ }^{2}$ Departemen IImu Penyakit Mulut, Fakultas Kedokteran Gigi Universitas Padjadjaran, Indonesia

*Korespondensi: elizakristinamunthe@amail.com

Submisi: 10 Oktober 2019; Penerimaan: 7 Juli 2020; Publikasi online: 31 Agustus 2020 DOI: $\underline{10.24198 / \mathrm{jkg} . v 32 \mathrm{i} 2.23868}$
\end{abstract}

\begin{abstract}
ABSTRAK
Pendahuluan: Necrotizing ulcerative stomatitis (NUS) merupakan inflamasi akut yang ditandai destruksi, ulserasi serta nekrosis epitel, jaringan ikat dan papila. Umumnya terjadi pada pasien malnutrisi dan Human Immunodeficiency Virus (HIV) seropositif. Lesi awal berupa necrotizing gingivitis kemudian berkembang menjadi necrotizing periodontitis, selanjutnya menjadi NUS. Gambaran klinis kasus NUS kadang serupa dengan Erythema multiforme (EM), sehingga perlu dilakukan pemeriksaan penunjang yang dapat menegakkan diagnosa dengan tepat. Tujuan laporan kasus ini melaporkan cara menegakkan diagnosis NUS yang menyerupai EM secara tepat pada pasien dengan suspek infeksi HIV. Laporan kasus: Pasien laki-laki berusia 49 tahun dirujuk ke departemen IImu Penyakit Mulut dengan diagnosis EM disertai suspek terinfeksi HIV. Keluhan utama berupa rasa nyeri disertai sariawan pada lidah dan bibir bagian dalam. Pemeriksaan ekstraoral tidak ada kelainan, pada intraoral ditemukan ulser multipel dilapisi sloughing kekuningan pada mukosa labial, mukosa bukal, dorsal lidah, lateral lidah dan ventral lidah. Gingiva anterior rahang bawah terdapat lesi ulseratif disertai jaringan nekrosis. Pemeriksaan darah menunjukkan penurunan hematokrit, peningkatan leukosit, serta negatif pada pemeriksaan tes HIV. Actinomyces naeslundii ditemukan pada pemeriksaan mikrobiologi. Ditegakkan diagnosis NUS dan terapi yang diberikan amoxicillin $500 \mathrm{mg}$, metronidazol $500 \mathrm{mg}$, chlorhexidine gluconate $0,2 \%$ dan asam folat. Lesi oral mengalami perbaikan dalam 2 minggu. Simpulan: Lesi oral mengalami perbaikan secara signifikan setelah kontrol ketiga atau seminggu dari kunjungan pertama, pasien sudah dapat makan tanpa rasa nyeri. Gambaran klinis lesi mukosa oral yang khas, serta pemeriksaan penunjang mikrobiologi berperan dalam menunjang diagnosis NUS. Tes HIV perlu dilakukan untuk mengkonfirmasi status infeksi HIV pada pasien. Dokter gigi sebaiknya mengenali tanda dan gejala NUS, sehingga dapat menegakkan diagnosis dan memberikan terapi adekuat serta mencegah meluasnya kerusakan jaringan.
\end{abstract}

Kata kunci: Human immunodeficiency virus, lesi oral, necrotizing ulcerative stomatitis, erythema multiforme.

\section{Necrotizing ulcerative stomatitis mimicking erythema multiforme in HIV seronegative patients}

\section{ABSTRACT}

Introduction: Necrotizing ulcerative stomatitis (NUS) is an acute inflammation characterised by destruction, ulceration, and necrosis of the epithelium, connective tissue, and papillae. Generally occurs in malnourished and Human Immunodeficiency Virus (HIV) seropositive patients. The initial lesion is found in the form of necrotizing gingivitis then developed into necrotizing periodontitis, which later became NUS. The clinical feature of NUS sometimes similar to the erythema multiforme (EM); thus, it is necessary to conduct investigations to make the diagnosis correctly. This case report was aimed to report on how to properly diagnose an EM-like NUS in a patient with suspected HIV infection. Case report: A 49-years-old male patient referred to the Oral Medicine department with an EM diagnosis with suspected HIV infection. The main complaint is pain accompanied by mouth sores on the tongue and inner lips part. Extraoral examination showed no abnormality, multiple ulcers coated with yellowish sloughing on the labial mucosa, buccal mucosa, dorsal tongue, lateral tongue, and ventral tongue. The anterior mandibular gingiva had ulcerative lesions with tissue necrosis. Blood tests showed a decrease in hematocrit, an increase in leukocytes, and a negative result of the HIV test. Actinomyces naeslundii was found on microbiological examination. Diagnosis of NUS was confirmed, and therapy given were amoxicillin $500 \mathrm{mg}$, metronidazole $500 \mathrm{mg}$, chlorhexidine gluconate $0.2 \%$, and folic acid. The oral lesions improved within two weeks. Conclusion: Oral lesions improved significantly after the third control in a week from the first visit, the patient was able to eat without pain. The clinical feature of typical oral mucosal lesions, as well as microbiological examinations, play a role in supporting the diagnosis of NUS. An HIV test needs to be carried out to confirm the HIV infection status of the patient. Dentists should recognise the signs and symptoms of NUS to determine a diagnosis, provide adequate therapy, and prevent the spread of tissue damage.

Keywords: Human immunodeficiency virus, oral lesions, necrotizing ulcerative stomatitis, erythema multiforme. 


\section{PENDAHULUAN}

Necrotizing Ulcerative Stomatitis (NUS) merupakan penyakit inflamasi pada rongga mulut yang ditandai destruksi epitel, jaringan ikat dan papila. ${ }^{1,2}$ NUS pertama kali dilaporkan pada tahun 1990 oleh Williams sebagai infeksi ulseratif nekrotik pada gingiva yang meluas ke jaringan mukosa dan palatal serta mengakibatkan kerusakan tulang. ${ }^{3}$ NUS dapat menyebabkan hilangnya perlekatan periodontal dan destruksi tulang, pada tahap lanjut dapat menyebabkan cancrum oris (NOMA). ${ }^{1,2}$ NUS dapat berasal dari necrotising ulcerative gingivitis (NUG) atau necrotizing ulcerative periodontitis (NUP) atau timbul pada mukosa mulut secara terpisah dari periodonsium. ${ }^{2}$ Ketiga penyakit ini dapat dipahami sebagai suatu proses penyakit yang sama karena mereka memiliki kesamaan etiologi, karakteristik klinis dan pengobatan, meskipun berbeda dalam tingkat keparahan penyakit. ${ }^{3,4}$

Prevalensi penyakit nekrosis periodontal lebih tinggi di negara berkembang, dibandingkan negara-negara industri, namun, prevalensi penyakit ini menurun secara signifikan selama abad kedua puluh. Penyakit ini lebih sering terjadi pada anakanak dan dewasa muda, lebih sering terlihat pada pasien HIV seropositif dan bisa menjadi penunjuk dalam mendiagnosis HIV dengan prevalensi 0-11\%. Pada pasien HIV seropositif yang telah mendapat terapi anti-retroviral, prevalensi nekrosis periodontitis tidak berbeda dari HIV seronegatif. 1,2,4,5 NUS jarang terlihat pada pasien HIV seronegatif terutama bila tidak terdapat kondisi medis yang mendasarinya, sehingga seringkali terjadi kesalahan menegakkan diagnosis ini dengan penyakit lain yang menyerupainya, atau menyebabkan seseorang dengan gambaran klinis NUS diduga terinfeksi HIV. ${ }^{1,2}$

Etiologi NUS umumnya disebabkan agen infeksius mikroorganisme spesifik bersifat komensal yang menjadi virulen ketika terjadi ketidakseimbangan sistem imun host sehingga menjadifaktorutamayang memfasilitasi patogenitas bakteri. Bakteri fusiform (Fusobacterium necrophorum), Spirochettes (Borrelia species), dan Pseudomonas aeruginosa telah diketahui terlibat pada NUS. ${ }^{2,6}$ Faktor predisposisi meliputi Infeksi HIV, diabetes mellitus, obat-obatan imunosupresi, anemia, malnutrisi, stres fisik dan emosional, merokok, agranulositosis atau neutropenia, kemoterapi, dan predisposisi genetik. Gangguan pada sistem imun dan respon inflamasi lokal dalam jaringan lunak mulut berkontribusi pada perkembangan lesi oral nekrotik. ${ }^{2}$ Patogenesis NUS bersifat multifaktorial, timbulnya penyakit merupakan kombinasi faktor yang satu dengan salah satu dari faktor lain, yaitu respon imun inang yang terganggu akan memfasilitasi patogenitas bakteri. ${ }^{6}$

Karakteristik klinis NUS ditandai dengan timbulnya ulser nekrotik pada papilary dan margin gingival yang ditutupi oleh pseudomembran putih kekuningan atau abu-abu sisa jaringan nekrotik, punched-out pada puncak papila, ulser yang terasa sangat nyeri dan disertai pendarahan spontan, yang meluas sampai alveolar ridges serta menyebabkan destruksi jaringan dalam rongga mulut. Gambaran klinis lain yang timbul meliputi halitosis, demam, limfadenopati servikal, disfagia, dan pada tahap lanjut terjadi pembentukan sequestrum. ${ }^{1,2,3,7}$ Penyakit ini dapat berkembang dengan cepat dan menyebabkan kerusakan jaringan yang parah.

Terapi yang tepat perlu segera diberikan kepada pasien, karena terdapat bukti yang menunjukkan bahwa penyakit ini dapat dikendalikan dengan perawatan periodontal yang adekuat dan dikombinasikan dengan tindakan oral hygiene serta kontrol faktor-faktor predisposisi. Perawatan umumnya sangat efektif jika diagnosis dini ditegakkan untuk mencegah berkembangnya NUS menuju NOMA. Terapi NUS meliputi debridemen, irigasi, dan oral hygiene instruction; antibiotik; analgesik; obat kumur; dan terapi suportif. Follow-up sangat penting untuk memantau kemajuan pengobatan dan rehabilitasi jaringan jika diperlukan. ${ }^{1,2,4}$

Ketidaktepatan diagnosis akan mempengaruhi terapi selanjutnya, sehingga diperlukan kehati-hatian. Erythema multiforme (EM) kadang memiliki gambaran klinis yang mirip dengan NUS, lesinya dapat terjadi di berbagai tempat dalam mukosa mulut, serta keterlibatan bibir berupa krusta yang mudah berdarah paling sering ditemukan dan menjadi ciri khas. Keterlibatan gingiva pada EM jarang terjadi, sehingga hal Ini dapat membedakan EM dengan NUS. 8,9,10,11

Laporan kasus ini membahas pasien yang dirujuk ke Departemen IImu penyakit Mulut (IPM) dengan diagnosa awal Erythema multiforme (EM) dan suspek HIV seropositif, namun berdasarkan 
hasil pemeriksaan lebih lanjut diagnosa tetapnya adalah Necrotizing ulcerative stomatitis (NUS) pada pasien dengan status HIV seronegative. Tujuan laporan kasus ini untuk melaporkan cara menegakkan diagnosis NUS yang menyerupai EM secara tepat pada pasien dengan suspek HIV seropositif (terinfeksi HIV). Pasien menyetujui kasusnya untuk dipublikasikan dengan menandatangani informed consent.

\section{LAPORAN KASUS}

Seorang pasien laki-laki berusia 49 tahun dirujuk ke Departemen IImu penyakit Mulut (IPM) RSUP dr Hasan Sadikin dengan diagnosis suspek erythema multiforme dan HIV. Keluhan utama berupa timbul rasa nyeri, sariawan pada lidah dan bibir, demam, lemah tubuh disertai bau mulut, dan perubahan rasa pengecap. Rasa nyeri tersebut menyebabkan pasien tidak dapat tidur dan mengalami kesulitan makan dan menelan sejak
7 hari sebelum masuk rumah sakit, ia berhenti menyikat gigi sehingga oral hygiene menjadi buruk, namun tidak mengalami penurunan berat badan selama mengalami nyeri. Pasien memiliki riwayat merokok 1 bungkus per hari selama kurang lebih 20 tahun.

Pemeriksaan ekstraoral tidak ditemukan adanya kelainan, sedangkan intraoral menunjukkan oral hygiene yang buruk disertai halitosis. Ulser ireguler ukuran sekitar $4 \times 2 \mathrm{~cm}$ dengan tepi eritema ditutupi sloughing kekuningan pada mukosa labial bawah. Ulser multipel ukuran sekitar $1 \mathrm{~cm}$, ireguler, ditutupi dasar nekrosis terlihat pada mukosa labial atas, dan mukosa bukal. Pada dorsal lidah, lateral lidah dan ventral lidah juga terdapat ulser ireguler ditutupi jaringan nekrotik ukuran $4 \times 2 \mathrm{~cm}$. Gingiva anterior rahang bawah terdapat ulser nekrosis disertai punched-out papila (Gambar $1 \mathrm{~A}-\mathrm{H})$. Terdapat kegoyangan gigi derajat 2 pada regio anterior rahang bawah yang menunjukkan keterlibatan jaringan periodontal. Pada palatum

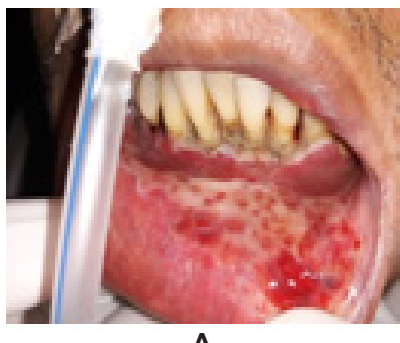

A

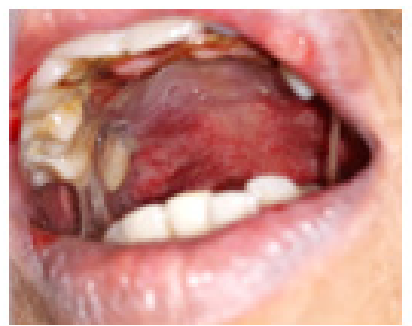

E

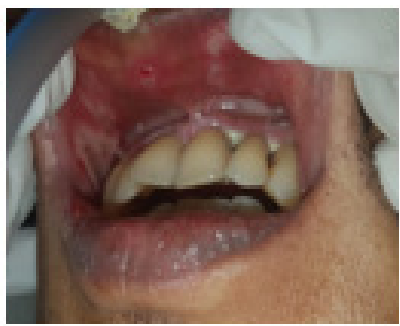

B

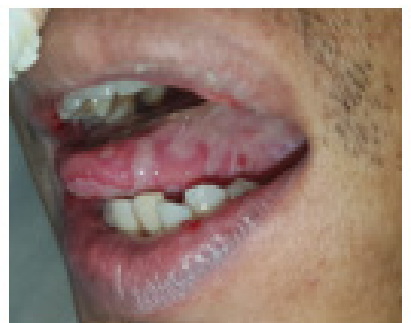

$F$

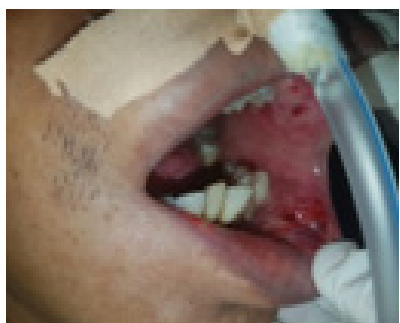

C

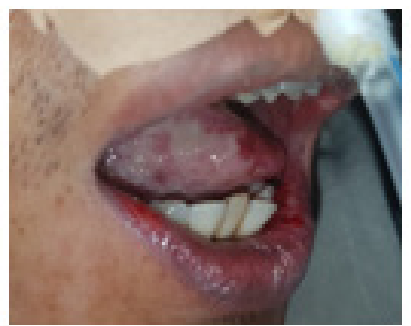

G

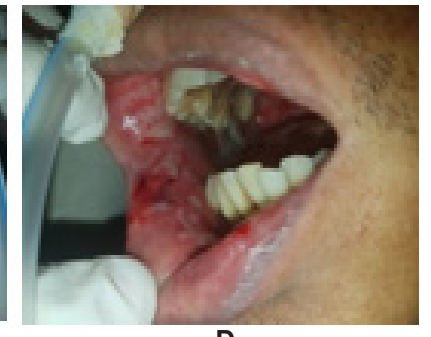

D

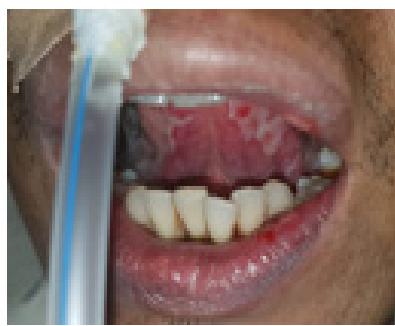

H

Gambar 1. Kondisi klinis pada kunjungan pertama (a-b) Ulserasi disertai jaringan nekrotik pada gingiva anterior rahang bawah, disertai ulser yang ditutupi sloughing kekuningan pada mukosa labial, (c-d) Ulser multipel pada mukosa bukal, (e)

Eritema pada palatum, (f-h) Ulser multipel ditutupi sloughing putih kekuningan pada dorsal, ventral dan lateral lidah.

mole terdapat eritema multipel ukuran $2 \times 2,5 \mathrm{~cm}$. Penilaian intraoral terbatas karena pasien nyeri saat membuka mulut.Pemeriksaan HIV didapatkan hasil negatif, dan pemeriksaan mikrobiologi menunjukkan pertumbuhan Actinomyces Naeslundii. Berdasarkan anamnesis serta pemeriksaan klinis ditegakkan diagnosis NUS. Hasil pemeriksaan laboratorium darah menunjukkan pasien tidak anemia namun terjadi penurunan hematokrit, dan peningkatan leukosit
(Tabel 1). Tatalaksana kasus ini meliputi terapi farmakologis yaitu meliputi amoxicillin $500 \mathrm{mg}$, metronidazol $500 \mathrm{mg}$ asam folat $1 \mathrm{mg} 3$ kali sehari dan chlorhexidine gluconate $0,2 \%$ mouthwash serta terapi non farmakologis yaitu diet cair tinggi kalori, tinggi protein 3 kali sehari karena pasien mengalami kesulitan makan sehingga asupannya berkurang. Penggunaan sikat gigi sebagai metode pembersihan tidak digunakan untuk sementara karena dapat mengganggu proses penyembuhan, 


\begin{tabular}{ccc}
\hline \multicolumn{2}{c}{ Tabel 1. Hasil pemeriksaan laboratorium } \\
\cline { 2 - 4 } Pemeriksaan & Hasil & Nilai Normal \\
Hemotogi 8 parameter & \\
Hematokrit & 14,4 & \\
Eritrosit & $40,7(\mathrm{~L})$ & $4,4-6,0$ juta/ul \\
Leukosit & 4,82 & $4,50-11,0$ 103/ul \\
Trombosit & $12,87(\mathrm{H})$ & $150-450 \mathrm{ribu} / \mathrm{ul}$ \\
MCV & 441 & $80-96 \mathrm{fl}$ \\
MCH & 84,4 & $27,5-33,2 \mathrm{pq}$ \\
MCHC & 29,96 & $33,4-35,5 \%$ \\
Imunoserologi Anti HIV & 35,4 & Nonreaktif \\
Mikrobiologi bakteri & Nonreaktif & \\
\hline
\end{tabular}

dan pasien diinstruksikan menggunakan chlorhexidine gluconate $0,2 \%$ mouthwash yang dikumurkan 3 kali sehari.

Follow-up 3 hari setelah perawatan pertama menunjukkan kondisi rongga mulut yang lebih baik, ulserasi serta jaringan nekrotik mulai mengalami penyembuhan dan ukurannya mulai mengecil. Pengukuran halitosis dengan metode langsung organoleptik yang dilakukan dengan mencium nafas pasien, ${ }^{12}$ didapatkan tingkat halitosis sudah berkurang dibandingkan kunjungan pertama, dan sudah tidak mengeluhkan nyeri saat membuka mulut. Pasien diinstruksikan untuk mulai melakukan tindakan oral hygiene yaitu menggunakan sikat gigi serta disarankan untuk berhenti merokok. Pada kunjungan ini terapi dari kunjungan pertama tetap

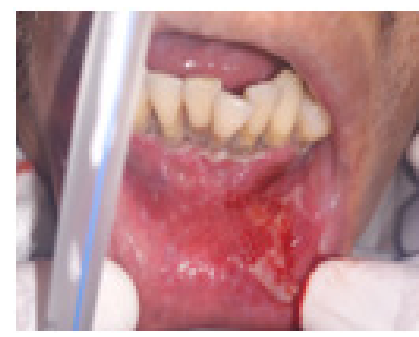

A

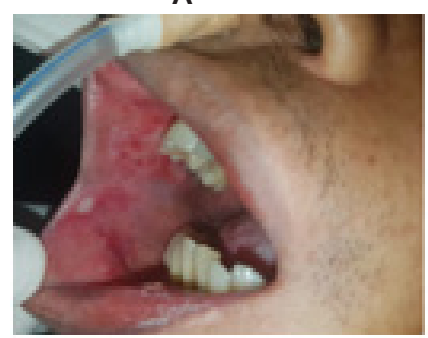

D

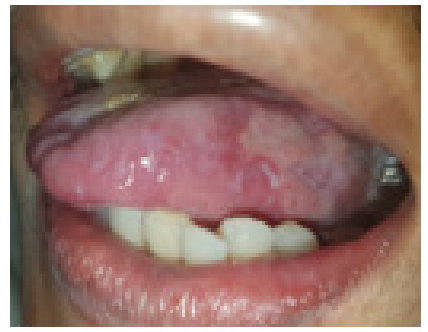

G

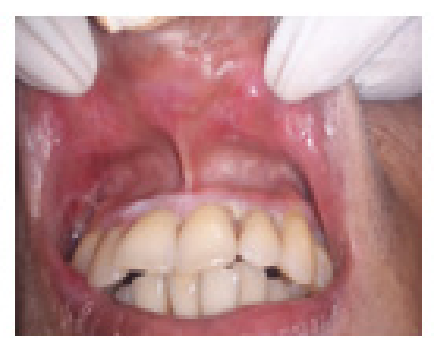

B

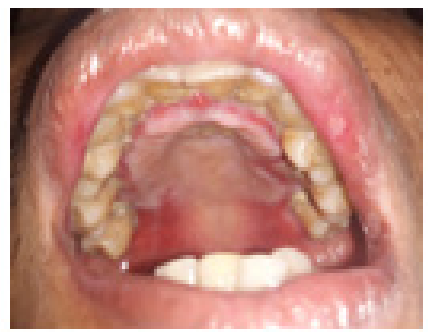

E

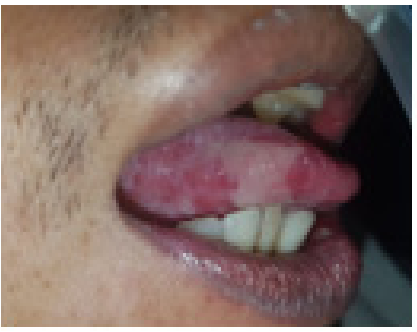

H

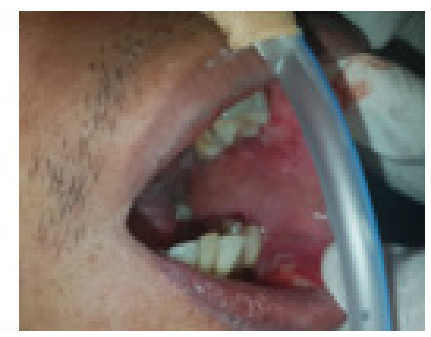

C

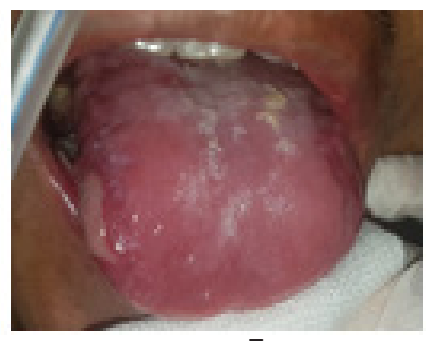

F

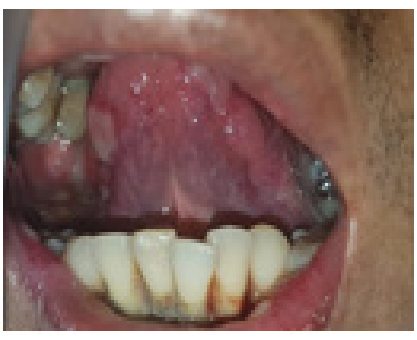

I

Gambar 2. Kondisi klinis pada kunjungan kedua. (a-b) Ulserasi disertai jaringan nekrotik pada gingiva anterior rahang bawah, dan ulser yang ditutupi sloughing kekuningan pada mukosa labial mulai mengalami penyembuhan, (c-d) Ulser multipel pada mukosa bukal mulai mengalami penyembuhan, (e) Eritema pada palatum mulai berkurang, (f- $\underline{\mathrm{h}} \mathrm{i})$ Ulser multipel ditutupi sloughing putih kekuningan pada dorsal, ventral dan lateral lidah mulai mengalami penyembuhan. 


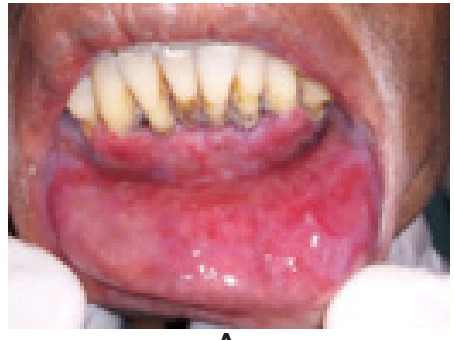

A

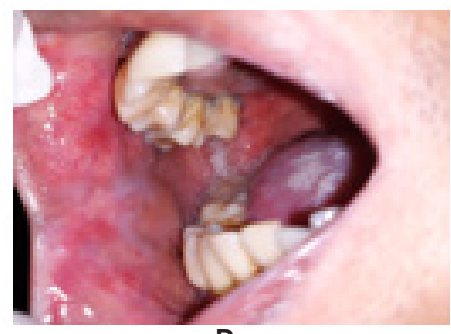

D

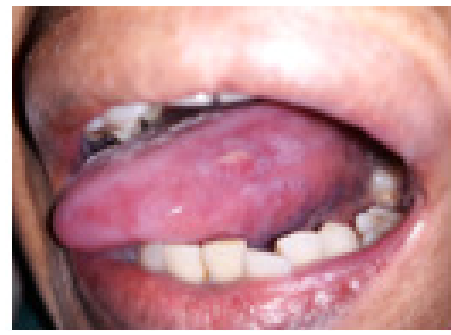

G

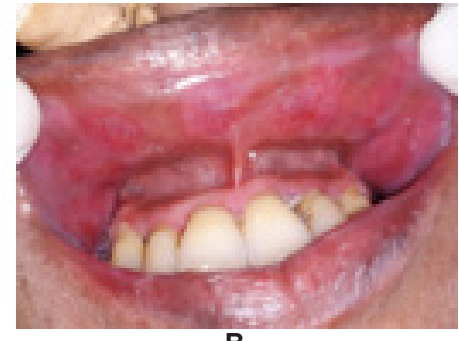

B

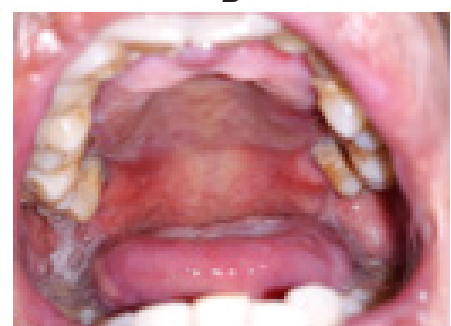

E

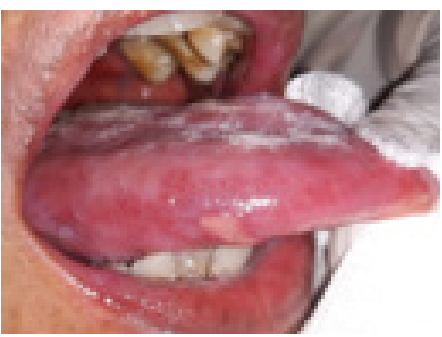

H

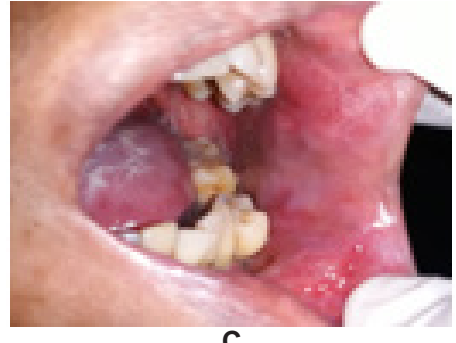

C

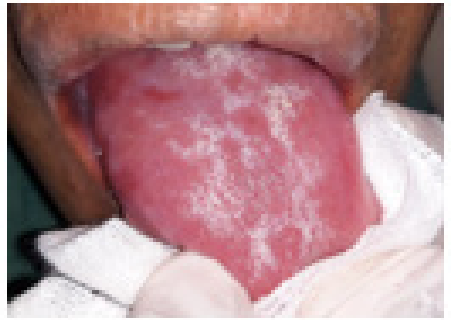

F

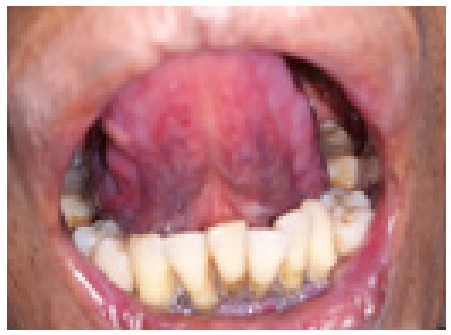

Gambar 3. Kondisi klinis pada kunjungan ketiga. (a-b) Ulserasi disertai jaringan nekrotik pada gingiva anterior rahang bawah, dan ulser yang ditutupi sloughing kekuningan pada mukosa labial sudah mengalami penyembuhan, (c-d) Ulser multipel pada mukosa bukal sudah mengalami penyembuhan, (e) Eritema pada palatum mulai berkurang, (f-i) Ulser multipel ditutupi sloughing putih kekuningan pada dorsal, ventral dan lateral lidah mulai mengalami penyembuhan.

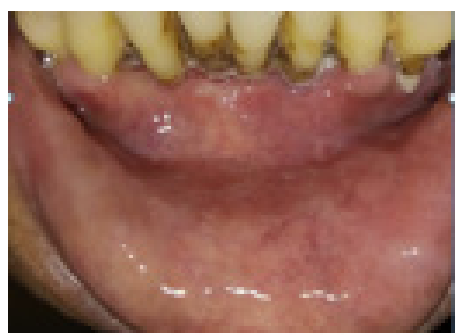

A

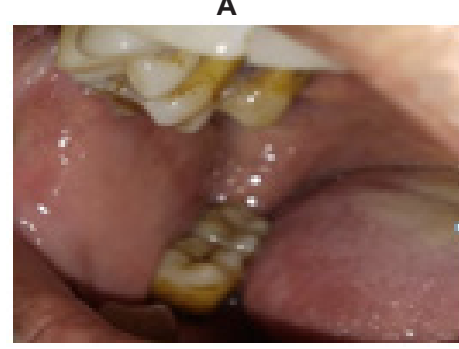

D

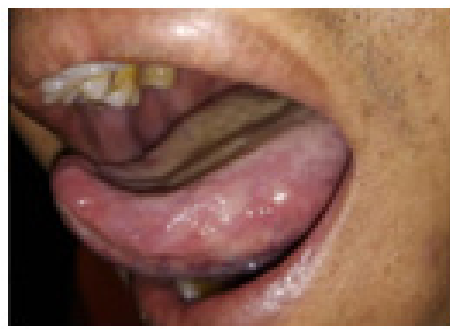

G

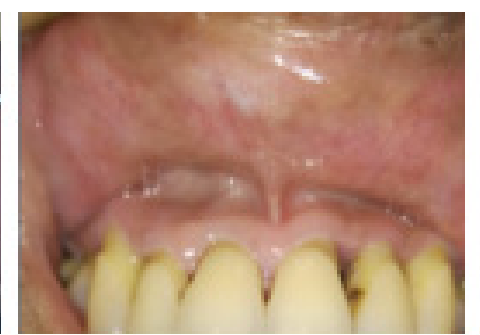

B

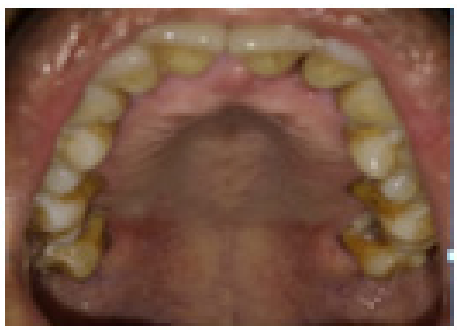

E

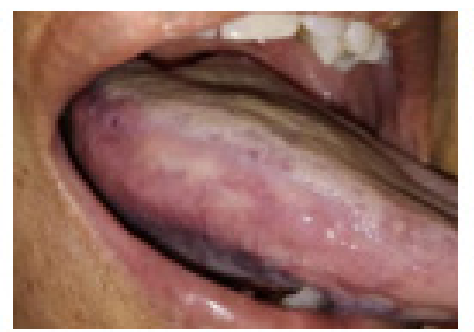

H

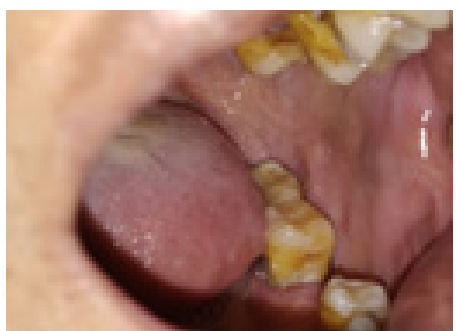

C

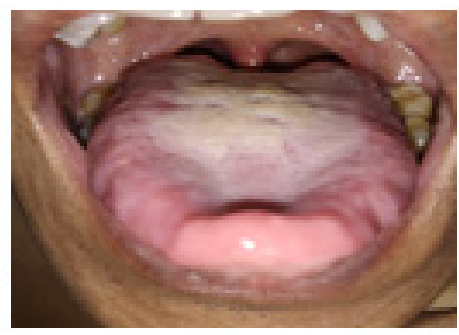

F

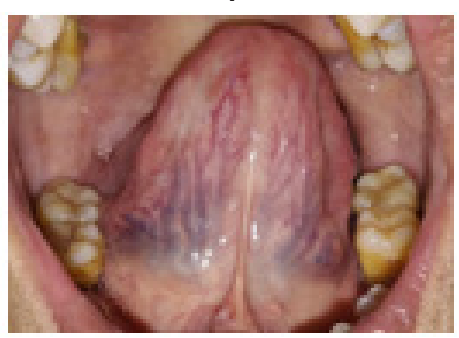

I

Gambar 4. Kondisi klinis pada kunjungan keempat (A-I) Ulser multipel sudah mengalami penyembuhan. 
dilanjutkan (Gambar 2A-I).

Kontrol ketiga (seminggu dari kunjungan pertama) lesi oral mengalami perbaikan secara signifikan seperti ditunjukkan pada gambar 3A-I, pasien sudah dapat makan tanpa rasa nyeri. Terapi amoxicillin $500 \mathrm{mg}$, metronidazol $500 \mathrm{mg}$, asam folat, dan chlorhexidine gluconate $0,2 \%$ mouth wash masih tetap dilanjutkan.

Dua minggu setelah kunjungan pertama pasien tidak datang kontrol, dan terapi farmakologis yang diberikan dihentikan penggunaannya oleh pasien dengan alasan kondisi rongga mulutnya sudah sembuh. Tiga minggu sejak kunjungan pertama lesi oral telah mengalami penyembuhan seperti ditunjukkan pada gambar $4 \mathrm{~A}-\mathrm{I}$.

\section{PEMBAHASAN}

Necrotizing ulcerative stomatitis adalah kelainan dalam rongga mulut dengan onset akut dan memerlukan terapi yang cepat. $^{7}$ Menegakkan diagnosis yang tepat sangat penting karena diagnosis dan perawatan yang salah akan memperburuk kondisi pasien dan dapat menyebabkan kematian. Diagnosis NUS umumnya didasarkan pada temuan klinis yang khas yaitu adanya ulser nekrotik diperkuat oleh pemeriksaan penunjang yaitu pemeriksaan mikrobiologi atau biopsi. ${ }^{1,2}$ Lesi biasanya dimulai pada papila interdental dan menunjukkan gambaran khas "punched-out", ujung papila interdental sering kali menjadi titik awal timbulnya lesi yang disebabkan kurangnya suplai darah pada epitel gingiva. Pendarahan gingiva spontan dan rasa nyeri dapat terjadi tiba-tiba sesuai tingkat keparahan lesi. Halitosis, adenopati, dan demam merupakan gejala yang menyertai, pseudomembran biasanya terbentuk pada daerah nekrotik papila interdental, apabila pseudomembran ini dilepaskan maka akan terjadi ulserasi, terlihatnya jaringan ikat disertai ujung saraf yang menyebabkan pendarahan dan rasa nyeri. ${ }^{13,14}$ Pasien pada laporan kasus ini tidak hanya mengalami nekrosis, ulser dengan pseudomemban, pendarahan spontan dan rasa nyeri, tetapi juga disertai halitosis dan demam.

Deteksi dan pengobatan dini NUG/NUP/ NUS sangat penting dalam mencegah tahap lanjut NUS menjadi noma. ${ }^{6,14}$ Diagnosis awal pasien ini adalah eritema multiforme. Eritema multiforme (EM) merupakan reaksi inflamasi akut pada kulit dan membran mukosa, yang ditandai erosi pada mukosa mulut yang khas mengenai bibir serta adanya target lesi pada kulit. EM terjadi sebagai akibat dari reaksi hipersensitivitas host terhadap infeksi atau obat-obatan. Lesi oral umumnya didahului vesikel dan bula yang cepat ruptur sehingga menyebabkan ulser, sering disertai perdarahan spontan meskipun pada sentuhan yang ringan. Lesi dapat terjadi di berbagai tempat dalam mukosa mulut, namun keterlibatan bibir paling sering terjadi dan menjadi ciri khas pada EM yang ditandai adanya krusta yang mudah berdarah, tetapi keterlibatan gingiva pada EM jarang terjadi, hal Ini menjadi kriteria penting untuk membedakan EM. Diagnosa EM umumnya ditegakkan dengan adanya lesi pada bibir dan adanya lesi target pada kulit. 8,9,10,11 Pada pasien ini tidak didapatkan lesi pada bibir dan lesi target pada kulit sehingga diagnosa EM menjadi tidak tepat.

Ketepatan dalam menegakkan diagnosis menentukan pemilihan obat sebagai terapi farmakologis. Terapi dari EM umumnya adalah pemberian kortikosteroid. Kortikosteroid merupakan obat yang memiliki efek imunosupresif dan dapat menjadi predisposisi terjadinya infeksi sekunder pada pasien, atau memperparah penyakit infeksi yang sudah ada. Pemberian kortikosteroid dapat memperburuk kondisi pasien yang sudah sangat terganggu, terutama pada pasien imunokompromis, sehingga pertimbangan menggunakan kortikosteroid harus lebih hatihati. ${ }^{1} 10,15,16$ Pada kasus ini pasien mengalami infeksi bakteri anaerob dengan gambaran klinis berupa NUS, sehingga perlu dihindari pemberian terapi kortikosteroid.

NUS dapat merupakan perkembangan penyakit dari nekrosis periodontal. Horning dan Cohen $^{6}$ menggambarkan tujuh tahap penyakit nekrosis periodontal sesuai dengan daerah yang terkena, dimulai dari nekrosis di ujung papila (stadium 1) hingga nekrosis dengan perforasi pada pipi (stadium 7). Gambaran klinis stadium 1 ditandai nekrosis hanya pada ujung papilla interdental, sedangkan stadium 2 nekrosis meliputi seluruh papila interdental. Pada stadium 3 nekrosis melibatkan gingival margin, dan pada stadium 4 nekrosis telah meluas pada attached gingiva. Stadium 5 nekrosis meluas pada mukosa bukal atau labial, dan pada stadium 6 , nekrosis sudah melibatkan tulang alveolar. Pada stadium 
7, nekrosis akan menimbulkan perforasi pada kulit pipi. ${ }^{6,7}$

Kelainan periodontal pada laporan kasus ini dikategorikan berada pada stadium 5 berdasarkan Horning dan Cohen, karena nekrosis yang terjadi telah meluas pada mukosa labial dan bukal. Ujung interdental papila gingiva biasanya merupakan awal mula dari NUG, kemungkinan besar karena suplai darah yang relatif lemah dari papillary dan margin gingival menjadi tempat timbulnya inflamasi yang diinduksi bakteri sehingga mengakibatkan iskemi dan nekrosis jaringan. ${ }^{17}$ NUG yang tidak diobati dapat menimbulkan nekrosis pada marginal periodontal attachment yang disebut NUP. NUG/ NUP selanjutnya dapat menyebar mempengaruhi mukosa alveolar, bukal, labial, lingual dan palatal, keadaan ini disebut NUS. Dalam sebuah literatur, disebutkan bahwa perkembangan NUG/NUP menjadi NUS dapat terjadi dalam waktu 24-48 jam. ${ }^{10,17}$ Respon seluler dan humoral host yang mengalami penekanan sistem imun oleh faktorfaktor seperti malnutrisi, infeksi virus dan bakteri, serta kondisi lain yang melemahkan, dapat terganggu oleh infeksi bakteri aerob dan juga anaerob sehingga menyebabkan NUG/NUP/ NUS. ${ }^{17}$

Plaut dan Vincent ${ }^{4,6,8}$ menyatakan bahwa bakteri adalah penyebab utama penyakit ini, dimulai ketika bakteri berproliferasi, sehingga flora normal rongga mulut tidak seimbang. Fusobacterium necrophorum, Treponema denticola, Porphyromonas gingivalis, Prevotella intermedia dll memainkan peranan penting dalam menyebabkan penyakit, bakteri memiliki kemampuan untuk menginvasi epitel dan jaringan ikat, serta melepaskan endotoksin yang menyebabkan destruksi jaringan periodontal. Timbulnya penyakit disebabkan karena patogenitas bakteri yang difasilitasi respon imun host yang menurun. Analisis mikrobiologi dari sampel plak subgingiva pasien menunjukkan adanya Actinomyces naes/undii. Data mikrobiologi dianggap tidak memberikan informasi diagnostik karena heterogenitas yang luas dari flora yang berperan dalam proses penyakit. ${ }^{7}$ Menurut komisi penelitian American Dental Association ${ }^{8}$ diagnosis NUG/NUP/NUS tidak hanya diperoleh melalui pemeriksaan mikrobiologi saja tetapi harus ada temuan secara klinis.

Biopsi umumnya tidak diindikasikan karena gambaran histologis NUS tidak spesifik. ${ }^{2}$ Gambaran histologis NUS digambarkan sebagai ulserasi ditutupi membran fibropurulen yang menunjukkan daerah nekrosis, histiosit vaskulitis disertai infiltrasi sel-sel inflamasi dan hiperemia dari lamina propria. Infiltrasi sel-sel inflamasi ini terdiri dari sel-sel atipikal besar dengan inti vesikuler diantara histiosit yang normal. ${ }^{2,3}$ Ekspresi CD68 dan HLADR4 dalam infiltrasi sel-sel inflamasi menegaskan bahwa sel-sel atipikal besar tersebut merupakan histiosit. Seringkali Herpes Simplex Virus (HSV), Epstein Barr Virus (EBV) dan Cytomegalovirus (CMV), dapat diidentifikasi secara histologis pada dareah ulserasi dan nekrosis. ${ }^{3}$

Faktor predisposisi penyakit nekrosis periodontal akan mengubah respon imun host, umumnya diperlukan lebih dari satu faktor untuk menginisiasi penyakit. Sebuah penelitian menyatakan bahwa, faktor predisposisi yang paling penting adalah infeksi HIV. Pada pasien non-HIV, faktor yang paling penting adalah adanya riwayat penyakit periodontal nekrosis sebelumnya, oral hygiene yang buruk, tidur yang tidak memadai, stres psikologis, pola makan yang buruk, penyakit sistemik, penggunaan alkohol, dan merokok. Pasien ini mempunyai riwayat merokok yang dapat menjadi faktor predisposisi timbulnya NUS. Sebagian besar pasien HIV seronegatif yang didiagnosis dengan penyakit periodontal nekrosis merupakan perokok. ${ }^{4,18}$ Nikotin pada rokok akan mengaktifkan sekresi noradrenalin dan adrenalin, yang menurunkan sirkulasi darah pada gingiva serta menginduksi vasokonstriksi pada pembuluh darah gingiva. Nikotin juga mengganggu keseimbangan rasio matrix metalloproteinases (MMP)/tissue inhibitors of metalloproteinases (TIMP), terjadi peningkatan jumlah MMP dan penurunan TIMP, sehingga meningkatkan kerusakan kolagen dan periodontal. Merokok dikaitkan dengan efek pada inflamasi dan respon jaringan, karena merokok akan mengganggu fungsi leukosit polimorfonuklear dan limfosit. $4,8,19,20,21$

Stres psikologis juga dapat mengaktifkan saraf simpatik dan mengurangi sirkulasi darah pada gingiva melalui sekresi adrenalin dan produksi perifer noradrenalin pada dinding pembuluh darah gingiva. Timbulnya vasokonstriksi disertai dengan endotoksin yang dihasilkan oleh bakteri gram negatif akan menyebabkantimbulnya penyakitperiodontal. ${ }^{9}$ Selama periode stres ini, tidak hanya respon imun 
yang diubah, tetapi juga perilaku pasien, yang menyebabkan oral hygiene dan diet yang buruk, atau peningkatan konsumsi tembakau. Mekanisme yang menjelaskan hubungan ini didasarkan pada penurunan mikrosirkulasi gingiva dan aliran saliva dan peningkatan kadar 17-hydroxycorticosteroid dalam serum dan urin, yang dikaitkan dengan perubahan fungsi leukosit polimorfonuklear dan limfosit sebagai fagositik dan kemotaktik, atau peningkatan jumlah bakteri patogen periodontal. Meningkatnya aktivitas adrenokortikal sebagai respon terhadap stres emosional akan mengubah sitokin yang mempengaruhi makrofag dan fibroblast sehingga menurunkan respon imun host terhadap patogen periodontal. Stres juga akan mengurangi jumlah MMP yang akan mempengaruhi turnover jaringan. Malnutrisi telah dilaporkan sebagai faktor predisposisi, yang dikaitkan dengan defisiensi nutrisi antioksidan seperti vitamin (asam folat, asam askorbat, B kompleks) dan mineral (seng, zat besi, magnesium, dll.) dan mengubah respon fase akut terhadap infeksi. Konsekuensi lainnya adalah timbulnya rasio terbalik antara limfosit T-helper dan limfosit T-supresor, peningkatan kortisol bebas dalam darah dan saliva serta defek pada integritas mukosa. ${ }^{4,22}$

Penyakit ini bersifat non self limiting dan jika tidak dilakukan pengobatan perjalanan penyakit akan terus berlanjut, karena itu intervensi dengan debridemen lokal, peningkatan oral hygiene, antibiotik dan nutrisi akan mencegah kerusakan rongga mulut. ${ }^{6,13}$ Penyembuhan lesi didapatkan melalui debridemen secara mekanis dan terapi antimikroba. ${ }^{4}$ Penatalaksanaan NUS terdiri dari pembersihan plak dan kalkulus serta debridemen jaringan keras dan lunak. Chlorhexidine gluconate $0,2 \%$ dan antibiotik dianjurkan untuk mengurangi jumlah bakteri. Metronidazol atau klindamisin umumnya dikombinasikan dengan amoxicillin. ${ }^{3}$ Pemberian antibiotik dapat menghentikan perkembangan penyakit, dan penggunaan obat kumur serta pembersihan gigi yang lembut dapat menghilangkan jaringan nekrotik. Penanganan nyeri, nutrisi, dan follow-up merupakan faktor penting yang perlu dipertimbangkan ketika merawat pasien NUS. ${ }^{3}$ Pemberian antibiotik, irigasi lesi, asupan elektrolit dan cairan, serta suplemen nutrisi pada NUS akan mencegah timbulnya osteonekrosis, myonecrosis, dan perforasi pada kulit. Bila kerusakan intra oral luas, debridemen tulang nekrotik, pencabutan gigi yang goyang serta rehabilitasi gigi mungkin diperlukan. ${ }^{13}$ Amoxicillin merupakan antibiotik spektrum luas yang efektif dalam pengobatan nekrosis periodontal yang disebabkan oleh sejumlah besar spesies mikroba yang terlibat dalam etiologi penyakit ini. ${ }^{7}$

Perawatan sebaiknya dibagi dalam tahap yang berurutan: pengobatan fase akut, fase perbaikan kondisi kronis rongga mulut, fase pengobatan / koreksi yang diakibatkan penyakit,dan fase suportif. ${ }^{4}$ Fase awal perawatan adalah pengobatan akut penyakit, yang bertujuan untuk menghentikan proses penyakit dan kerusakan jaringan; serta mengontrol rasa nyeri yang mengganggu asupan nutrisi dan oral hygiene pasien. Pasien mengeluhkan rasa nyeri pada rongga mulut yang membuat pasien sulit makan, sehingga debridemen mekanik seperti menyikat gigi tidak mungkin dilakukan karena dapat menunda penyembuhan dan menyebabkan perdarahan serta rasa nyeri. ${ }^{12}$ Tindakan oral hygiene secara mekanis sebaiknya dibatasi karena menyikat daerah yang luka dapat menghambat proses penyembuhan dan menimbulkan rasa nyeri. Selama periode ini pasien pada laporan kasus ini disarankan untuk menggunakan chlorhexidine gluconate $0,2 \%$ mouth wash, yang tidak hanya berperan pada pembersihan kimiawi tetapi juga memberikan efek antibakteri yang akan mempercepat penyembuhan klinis yang lebih cepat dan kerusakan periodontal yang lebih sedikit. Pasien juga diberikan metronidazol 500mg dikombinasikan dengan amoxicillin $500 \mathrm{mg}$. Metronidazol menjadi pilihan pertama karena aktif melawan bakteri anaerob. Obat-obatan antimikroba lain seperti golongan penisilin, tetrasiklin, klindamisin, juga efektif terhadap bakteri periodontal. ${ }^{4,12}$ Selain diberikan chlorhexidine gluconate $0,2 \%$ mouthwash, amoxicillin $500 \mathrm{mg}$ dan metronidazol $500 \mathrm{mg}$, pasien ini juga diberi diet cair tinggi kalori dan tinggi protein untuk memperbaiki nutrisi. Respon pasien terhadap terapi yang diberikan cukup baik terlihat dari lesi ulserasi dan jaringan nekrotik mengalami penyembuhan yang signifikan.

Pada fase pengobatan awal, dianjurkan penggunaan chlorhexidine hingga dua minggu. Setelah beberapa hari, nyeri di tepi gingiva dan papilla akan berkurang, sehingga pembersihan gigi dapat dilakukan. Fase pengobatan kedua yaitu perbaikan kondisi yang sudah ada sebelumnya. 
Pada fase ini, gejala akan membaik setelah fase akut awal; Oleh karena itu, scaling dan root planing bersama dengan instruksi oral hygiene harus dimulai. Selanjutnya, pengendalian faktor sistemik dengan, misalnya berhenti merokok, menjaga tidur yang cukup dan mengurangi stres, harus dilakukan. Fase ketiga memerlukan pengobatan/ koreksi yang diakibatkan penyakit; seperti, gingivektomi atau flap periodontal dilakukan untuk memperbaiki crater yang dalam. Perawatan bedah harus dipertimbangkan hanya jika dianggap perlu setelah perawatan oral hygiene yang benar. Tahap perawatan keempat dan terakhir dilanjutkan dengan terapi periodontal suportif untuk menjaga kebersihan mulut dan mengendalikan faktor sistemik.

Setelah fase akut sudah terkontrol, fase pengobatan selanjutnya adalah perbaikan kondisi kronis rongga mulut yang sudah ada, meliputi tindakan profilaksis dan/atau scaling dan root planing, disertai instruksi oral hygiene. Pada tahap ini, dan juga selama fase akut, pengendalian terhadap faktor predisposisi sistemik tetap diperhatikan, termasuk menghentikan merokok, tidur yang cukup, dan mengurangi stres. Fase ketiga adalah fase pengobatan / koreksi yang diakibatkan penyakit seperti gingival craters, melalui prosedur gingivektomi dan/atau gingivoplasty. Fase perawatan terakhir adalah fase pemeliharaan, dengan tujuan mempertahankan kebersihan mulut dan kontrol faktor predisposisi. ${ }^{4,12}$ Pasien dengan nekrosis periodontal juga rentan mengalami rekurensi penyakit, hal ini umumnya diakibatkan kesulitan dalam mengendalikan faktor predisposisi serta mempertahankan oral hygiene dalam hal ini yaitu kontrol supragingival biofilm. ${ }^{4}$ Selanjutnya, pasien disarankan untuk berhenti merokok, mempertahankan tidur yang cukup, mengurangi stres serta mencukupi asupan nutrisi. Pasien menunjukkan respons yang sangat baik selama perawatan di bagian IImu Penyakit Mulut

\section{SIMPULAN}

Lesi oral mengalami perbaikan secara signifikan setelah kontrol ketiga atau seminggu dari kunjungan pertama, pasien sudah dapat makan tanpa rasa nyeri. Gambaran klinis lesi mukosa oral yang khas, serta pemeriksaan penunjang mikrobiologi berperan dalam menunjang diagnosis NUS. Tes HIV perlu dilakukan untuk mengkonfirmasi status infeksi HIV pada pasien. Dokter gigi sebaiknya mengenali tanda dan gejala NUS, sehingga dapat menegakkan diagnosis dan memberikan terapi adekuat serta mencegah meluasnya kerusakan jaringan.

\section{DAFTAR PUSTAKA}

1. Agbelusi GA, Eweka OM. Necrotising stomatitis as a presenting symptom of HIV. Open $\mathrm{J}$ Stomatol. 2011; 1(4): 168-71. DOI: 10.4236/ OJST.2011.14025

2. Abah AA, Agbelusi GA. Necrotizing Stomatitis in a Non-HIV Patient: A Case Presentation. J Case Reports Med. 2013; 1:1-4. DOI: 10.4303/ $\mathrm{jcrm} / 235723$

3. Peters SM, Heinz MJ, Koslovsky DA, Yoon AJ, Philipone EM. Necrotizing ulcerative stomatitis as initial presentation of undiagnosed HIV infection: A case report and review of literature. J Oral Maxillofac Surgery, Med Pathol. 2017; 29(6): 570-4. DOI: 10.1016/j. ajoms.2017.07.005

4. Herrera D, Retamal B, Valdes, Alonso B, Feres M. Acute periodontal lesions (periodontal abscesses and necrotizing periodontal diseases) and endo periodontal lesions. J Clin Periodontol. 2018;45(Suppl 20):S78-S94. DOI: $10.1111 /$ jcpe. 12941

5. Assimii S, Adallaoui L, Ennibi O. Acute necrotizing periodontitis : a case report. Austin J Dent. 2016; 3(3): 1041.

6. Adesh S. Manchanda, Kaur N, Kaur N. Intricacies In Investigating Necrotising Ulcerative Stomatitis- A Case Report. Int J Com Health and Med Res. 2016; 2(4): 64-8. DOI: 10.21276/ijchmr.2016.2.4.12

7. Magan-Fernandez A, O'Valle F, Pozo E, Liebana J, Mesa F. Two cases of an atypical presentation of necrotizing stomatitis. J Periodontal Implant Sci. 2015; 45(6): 252-6. DOli: 10.5051/jpis.2015.45.6.252.

8. Bashir T, Vijay K. Erythema Multiforme: A Case Report.Journal of Indian Academy of Oral Medicine \& Radiology. 2014; 2(7): 249-51.

9. 9. Patil B, Hegde S, Naik S, Sharma R. Oral blistering - report of two cases of erythema multiforme \& literature review. J Clin Diagn Res. 2013; 7(9): 2080-3. DOI: $\underline{10.7860 /}$ 
JCDR/2013/5171.3412.

10. 10. Bajaj P, Sabharwal R, PK Mohammed R, Garg D, Kapoor C. Erythema Multiforme: Classification and Immunopathogenesis. J Adv Med Dent Scie 2013; 1(2): 40-47.

11. Joseph TI, Vargheese G, George D, Sathyan P. Drug induced oral erythema multiforme: A rare and less recognized variant of erythema multiforme. J Oral Maxillofac Pathol. 2012; 16(1): 145-8. DOI: $10.4103 / 0973-029 X .92995$.

12. Kwon E-Y, Choi Y-K, Choi J, Lee J-Y, Joo J-Y. Effective Management of Acute Necrotizing Ulcerative Gingivitis with Proper Diagnosis and Immediate Treatment. J Korean Dent Sci. 2016;9(2):81-9. DOI: 10.5856/ JKDS.2016.9.2.81

13. Todescan S, Nizar R. Managing patients with necrotizing ulcerative periodontitis., Journal (Canadian Dental Association). 2013. Vol. 79. p. d44.

14. 14. Masipa JN, Baloyi AM, Khammissa RAG, Altini M, Lemmer J, Feller L. Noma (cancrum oris): a report of a case in a young AIDS patient with a review of the pathogenesis. Head Neck Pathol. 2013; 7(2): 188-92. DOI: 10.10071 s12105-012-0393-0

15. Law EH, Leung M. Corticosteroids in StevensJohnson Syndrome/toxic epidermal necrolysis: current evidence and implications for future research. Ann Pharmacother. 2015; 49(3): 335-42. DOI: $10.1177 / 1060028014560012$.

16. 16. Liu D, Ahmet A, Ward L, Krishnamoorthy
P, Mandelcorn ED, Leigh R, et al. A practical guide to the monitoring and management of the complications of systemic corticosteroid therapy. Allergy, Asthma Clin Immunol. 2013; 9(1): 1-30. DOI: 10.1186/1710-1492-9-30

17. Feller $L$, Altini $M$, Chandran R, Khammissa RA, Masipa JN, Mohamed A, Lemmer J. Noma (cancrum oris) in the South African context. J Oral Pathol Med. 2014 ; 43(1): 1-6. DOI: 10.1111/jop.12079.

18. Zia A, Mukhtar-Un-Nisar Andrabi S, Qadri S, Bey A. Necrotizing periodontitis in a heavy smoker and tobacco chewer - A case report. Singapore Dent J. 2015; 36: 35-8. DOI: 10.1016/j.sdj.2015.07.001.

19. Sapna G, Gokul S, Bagri-Manjrekar K. Matrix metalloproteinases and periodontal diseases. Oral Dis. 2014; 20(6): 538-50. DOI: $10.1111 /$ odi.12159.

20. Franco C, Patricia HR, Timo S, Claudia B, Marcela $\mathrm{H}$. Matrix Metalloproteinases as Regulators of Periodontal Inflammation. Int J Mol Sci. 2017. 17;18(2):440. DOI: 10.3390/ ijms18020440.

21. Sangani I, Watt E, Cross D. Necrotizing ulcerative gingivitis and the orthodontic patient: a case series. J Orthod. 2013; 40(1): 77-80. DOI: 10.1179/1465313312Y.0000000037.

22. Fatima Z, Bey A, Gupta ND. Conservative management of acute necrotizing ulcerative gingivitis in lactating female. Int Dent $\mathrm{J}$ Student'S Res. 2013; 1(4): 42-6. 